素より地域は靜的なものではなく，その安定度その持續性には自ら相異が あり，云わ代常に不安の狀態在るのかも知れない。

篔てサヴ フンナや森林地て確乎をる王國を等いていたョルバやべニンの地 方も今は崩解て瀕している。市場イバダンの如きも現在は恐らくョルバの 市場としてよりも，沙漠を越えてハウサ族のキ+ラヴ フンの來往する折返し 終點としてむしろティンブクトゥ,ソコト，カノ等と共に沙漠と云ら大地域 の境界市場に轉化して了つた之考えれ方がよいである。

然し純粹な地理學的地域は，かくの如き生成之崩解の過程を通して，生命

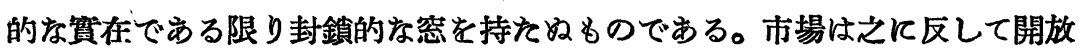
的学そのものである。しかもとの二つは同時に存在する。南ジェリアイ於 ては命令によつてさ充も同時に存在せねばならない。之は如何なるととを意 味しているのであららか。

私はれぶかくの如き緊張した秩序の中にのみた之え瞬時にもせ上地理學的 な地域の質在を發見したいのである。凡ゆる地域構造の底て非連續の連續の あるととを受容しれいのである。

\title{
神戶市の都心ととの變 遷
}

藤本利 治

神巨の都心は西加ら東方に向っている。即ち大輸田泊，融原 (現在兵庫區附近) 加ら開港以後は走水・ニッ茶屋・神戶村 (現在の生田區附近) 一, 更に大正末・昭和 


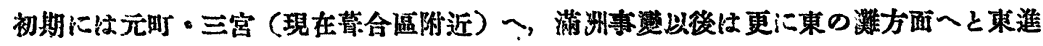

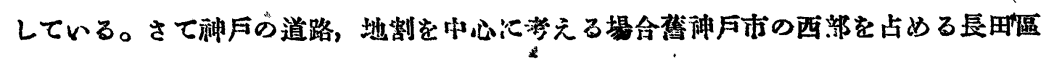
・須磨區は東西及び南北に規則正しく道路方建設されて不完全ながら都市計畫に基い

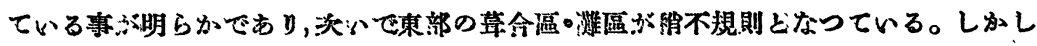
との西にある生田區は更汇不规則で，港を中心に人口の自然加と共に逐年的・不规 則的に路脹し發展していった事を明潦に示している。兵莗區に至ると狄い道路・袋小 路・路地等があらゆる中貝と方向をもって起没され，全く不縄一・不規則で乱雜を極 めている。か人各地域に於汀る道路網加ら，まずとの兵庫區附近が神户の最も古い地

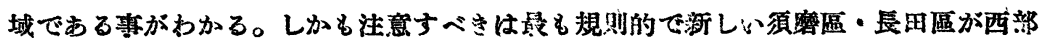

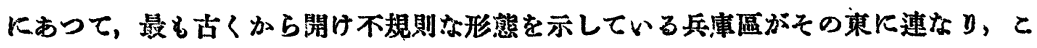

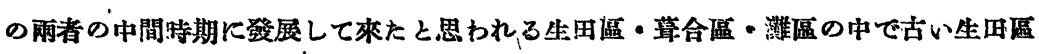

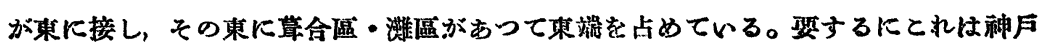
の䇥展に竍つて都心も西上り東に進み最後に西に向つた事を示している。

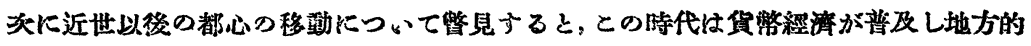

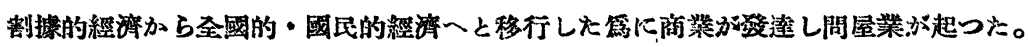

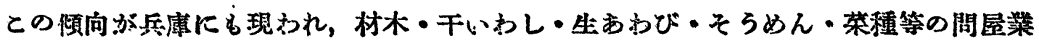

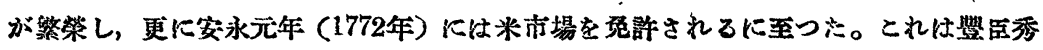

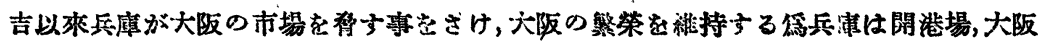

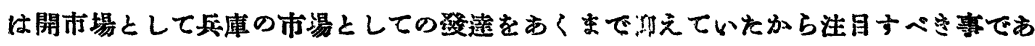

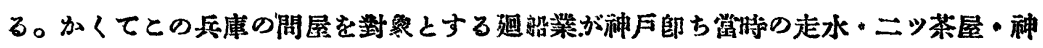

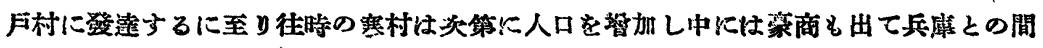

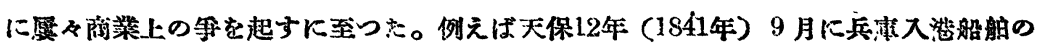

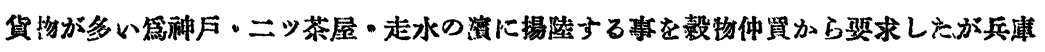

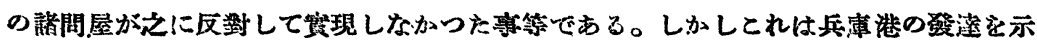

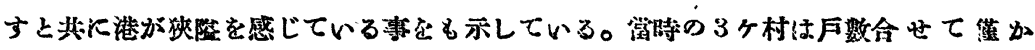
1000户余りで近䑡迄は泟めて㝝しい小村であつた。

即与神戶祄人口は

1690年 (元醁 3、年)

1391人

1760年 (竇魔10年)

1985人 
1830年（文政13年）

1840年 (天保11年)

1850年 (嘉永 3 年)

1858年 (安政 5 年)

これに䍌して兵瑓津の人口は

1716年（享保年間）

1739年 (元文 4 年)

1769 年 (明和 6 年)

1787年 (天明门年)

1861年 (文久元年)

1869年 (元治元年)
2637人

2442人

2547人

2605 人”

19766人

20546人

21912人

19588人

20061人

19556人

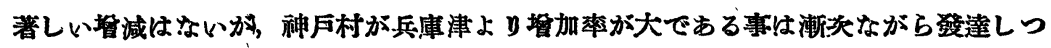
つある事を示すのであつて、ほとんど人口增減のなかつた德川時代にあつてこの增加 來は注意す心゙き現象である。更に登展を逐げる端緒となつたものは實に神戶開港で， 以後都心は兵庫から神戶ーと移り，慶應 3 年 (1867年) 12 月 7 日以後兵庫港と神戶港 とはその地位を全く頩倒するに至つたのである。

都心の移動の事實はとの開港と共に港町としてのほかに商工業都市へと指向した職 菜別戸数の變化によつても窥われる。郎ち

\begin{tabular}{|c|c|c|c|c|}
\hline 年次 & 明治30年 & 明治40年 & 大正 3 年 & 大正 7 年 \\
\hline 農＼cjkstart業 & 425 . & 069 & 224 & 129 \\
\hline 工 業 & 696 & 1335 & 3566 & 8774 \\
\hline 辣業 & 3026 & 3327 & 4571 & 4434 \\
\hline 其 、他 & 5853 & 5296 & 1634 & .1643 \\
\hline
\end{tabular}

商工業の發達特に工業の躍進が顯著であるが，とれらは原料・紎料・製品の運搬に便 利な神戸港及び港と陸運の連絡のよい元町・三宫地域一伸展した。更に昭和以後は戰 争の篇廣大な工場僌地と大量運搬の交通網を要する重工業が登達したが，これらが新 市街灘區二伸長したのは當然で，縝く太本洋戰争に舊神戶の工業は飽和狀態となつた 


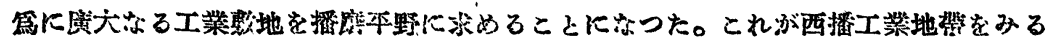
に至つた一因である。商樂も從本は兵庫の御旅町地域が中心であつたが，元町・三宮 一と移行して御旅町は现今は唯兵庶附近の中心に過を゙なくなつた。次に最近の狀势を みると地理的に賞然明石市に䋧入されるべき垂水町を合併し，更に22年 3 月には明石

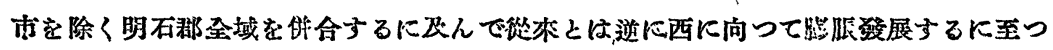

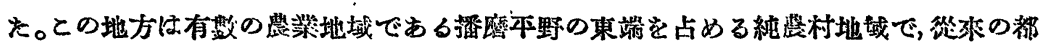

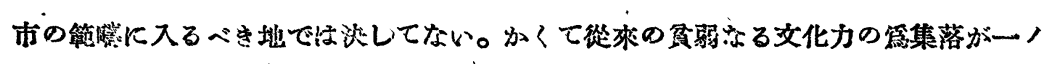

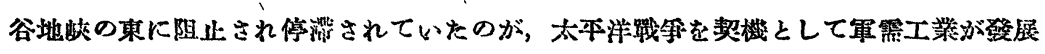

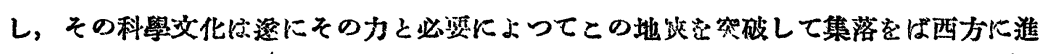
出するに至らしぬた。かくて東進していた集落は，商港を中心にして發展している滴

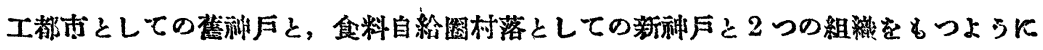

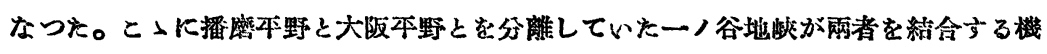

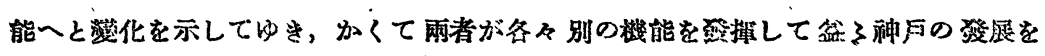

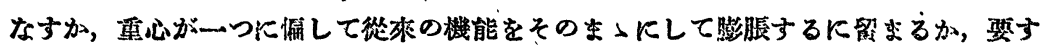

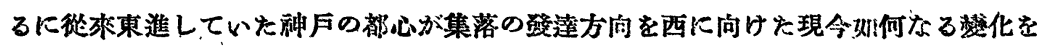
みせるか，とれが單なる現在の食料不足を打開して食料自給圈を磪立せんとする施矮

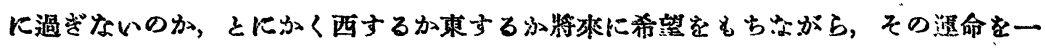
/谷地陝と文化力の均衡に求めているのでけ就いる考元る。

しからば大阪を近くに控えながら何故に最初は東へ東へと發展し，更に最近には西

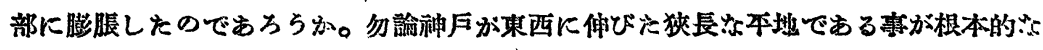

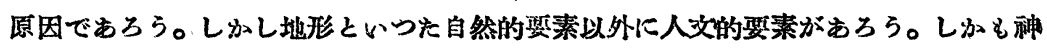
Fの都心の東への移動吕古代畿內汶化が西入流れた經路上の糸地を占めている等を

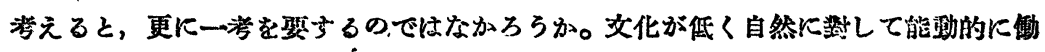
くカの弱い時代にあつては，一ノ谷地炏がその決定的な要因をなしたであるら。郎ち

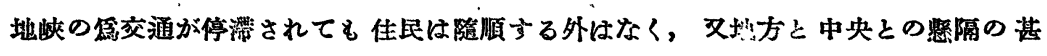
しかつた古代では，貴族文化，都市的文化を受け入れるだけの高度の美地をもつた文

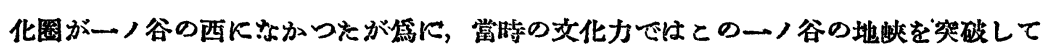

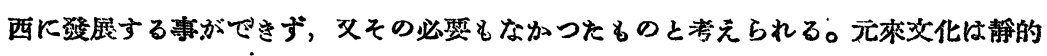

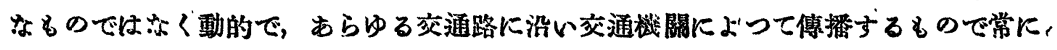

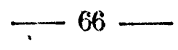




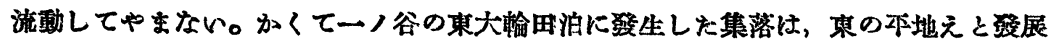

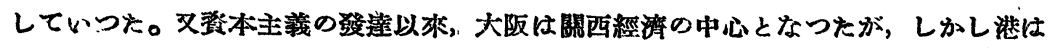
自然倐件の不良，設倩の貧弱港灣行政機關の不借等で惠まれず，その原料，燃料，製

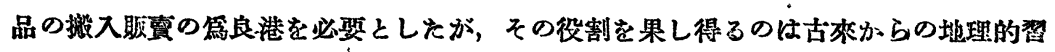

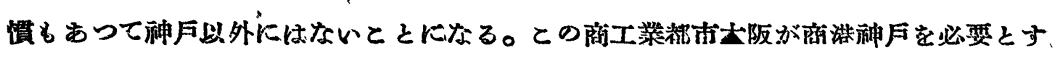

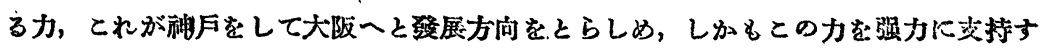

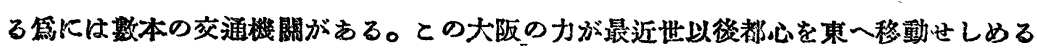

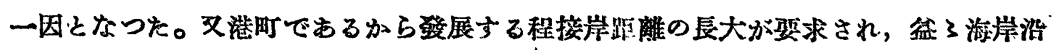
いK伸長する，殊に重工掌が發達すると海洋がその連搬路となるから，その海岸沿い

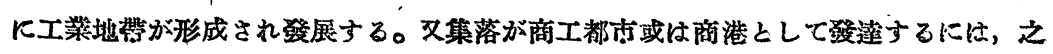

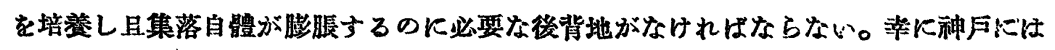

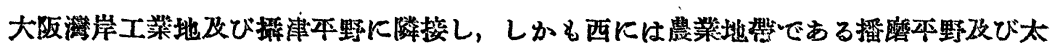

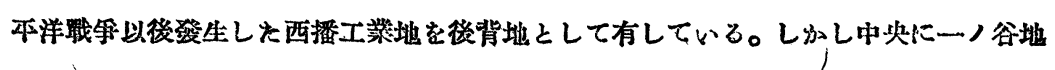

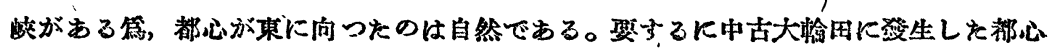

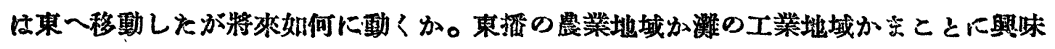
ある課題である。

\section{瓷料}

オンシス・タシン(泉地集落)の性格

\section{辻田右左男}

\section{はしがを}

荒凉㝡莫，何らの越力も潤いもない，いわば死の世界である沙漠地紫に，局部的て はあるが殷䀼愉樂，人口が蝟集し，粶したたる園池の見出される，认かば生の溃所で あるオアシスが存在ずるといらとは、たしかに天の配劑といわなければならない。 まととにォアシスはブリューンのいら如く，沙漠の“島”であり，またせームズのた とえた如く，沙漠の旅人がオアシス町にたどりつい゙た時は，船乘りが，目ざす港に着 くのと同じ樂しい思に满たされるととであるら。今, とのオアシス闭形成されるォア 